\title{
Effect of cultivar and seed rate on weed infestation and crop performance of wheat
}

\author{
PK Halder, M Salim, SK Paul*
}

Department of Agronomy, Bangladesh Agricultural University, Mymensingh 2202, Bangladesh

\begin{abstract}
An experiment was carried out at the Agronomy Field laboratory of Bangladesh Agricultural University, Mymensingh during the period from November 2014 to March 2015 to study the effect of cultivar and seed rate on weed infestation and crop performance of wheat. Three wheat cultivars viz. BARI Gam 24, BARI Gam 25 and BARI Gam 26 and five seed rates viz. 80, 90, 100, 110 and $120 \mathrm{~kg} \mathrm{ha}^{-1}$ were considered as the experimental treatment. The experiment was carried out in Randomized Complete Block Design with three replications. The cultivar and seed rate were significantly influenced on weed infestation and crop performance of wheat. The dry weight of weeds in cultivar BARI Gam 26 was the lowest $\left(9.24 \mathrm{~g} \mathrm{~m}^{-2}\right)$ compared to other cultivars. The lowest dry weight of weed was recorded in the seed rate of $120 \mathrm{~kg} \mathrm{ha}^{-1}\left(7.57 \mathrm{~g} \mathrm{~m}^{-2}\right)$ and the highest one $\left(16.14 \mathrm{~g} \mathrm{~m}^{-2}\right)$ was produced in seed rate of $80 \mathrm{~kg} \mathrm{ha}^{-1}$. The highest plant height $(93.27 \mathrm{~cm})$, number of effective tillers plant ${ }^{-1}$ (3.69) and 1000-grain weight (44.51g) were produced in BARI Gam 25. The highest number of spikelet spike ${ }^{-1}$ (18.12) and grains spike ${ }^{-1}$ (34.51) were produced by BARI Gam 26. BARI Gam 26 produced the highest grain yield $\left(2.51 \mathrm{t} \mathrm{ha}^{-1}\right)$ which was as good as BARI Gam $25\left(2.48 \mathrm{t} \mathrm{ha}^{-1}\right)$. BARI Gam 26 produced the highest grain yield with $100 \mathrm{~kg}$ seed rate and also a good competitor against weeds. Seed rate was a reliable factor where increasing seed rate reduced the weed dry weight production. In conclusion, cultivation of BARI Gam $26 @ 100$ $\mathrm{kg} \mathrm{ha}^{-1}$ seeds may be cultivated for higher grain yield.
\end{abstract}

Key words: Cultivar, seed rate, weed infestation, crop performance, wheat

Progressive Agriculturists. All rights reserve

*Corresponding Author: skpaull@gmail.com

\section{Introduction}

Wheat is one of the most nutritious cereals and its contribution to human diet puts it in the first rank of plant that feed the world. It ranks first in area (218.5 million hectares) and third in production (713 million metric tons) among the grain crops in the world (FAO, 2013). In Bangladesh, wheat ranks next to rice in respect of production (1.3 million metric tons) and total area of 0.43 million hectares (BBS, 2013). Though, wheat is an important cereal crop in Bangladesh its average yield is low compared to other wheat growing countries of the world.

Weeds are undesirable plants, which infest different crops and inflict negative effect on crop yield either competition for water or nutrients or space or light
(Reddy and Reddi, 2011). Weeds are notorious yield reducers that are, in many situations, economically more important than insects, fungi or other pest organisms. It has been estimated that globally yield reduction of wheat due to weeds is $13 \%$ (Oerke et al., 1994). Generally weed-crop competition is complicated as weeds are competitor of crop plant by occupying space, light, moisture and nutrient.

High yield of wheat depends on many factors but variety is considered as the key factor among them, because different varieties respond differently to their input requirements. Wheat varieties differ significantly in producing various yield components and yield (Hasan, 1995). Gail et al. (2004) found that 
total weed density was negatively correlated with the number of winter wheat stems $/ \mathrm{m}^{2}$.Seed rate influences the yield and yield contributing characteristics of wheat (Singh and Singh, 1987). Higher amount of seed rate generally increases plant population resulting intra-crop competition thereby affecting the yield. On the other hand, lower seed rate may reduce the yield drastically as the grain yield is positively correlated with plant population (Vukadinovic et al., 1986). With these end in view an attempt was undertaken to evaluate the effects of different cultivars and seed rates on weed infestation and crop performance of wheat.

\section{Materials and Methods}

The experiment was carried out at the Agronomy Field Laboratory of the Bangladesh Agricultural University, Mymensingh during the period from November 2014 to March 2015 to investigate the effect of cultivar and seed rate on weed infestation and crop performance of wheat. The experimental site is located at $24.75^{\circ} \mathrm{N}$ latitude and $90.50^{\circ} \mathrm{E}$ longitude at an elevation of $18 \mathrm{~m}$ above the mean sea and belongs to Old Brahmaputra Floodplain (AEZ-9) (UNDP and FAO, 1988). The experimental field was a medium high land with non-calcareous dark-grey floodplain soil and silty clay loam texture having $\mathrm{pH}$ 6.8 .

Three wheat cultivars viz. BARI Gam 24, BARI Gam 25 and BARI Gam 26 and five seed rates viz. $80,90,100,110$ and $120 \mathrm{~kg} \mathrm{ha}^{-1}$ were considered as the experimental treatment. The experiment was carried out in Randomized Complete Block Design with three replications. The unit plot size was $4.0 \mathrm{~m}$ x $2.5 \mathrm{~m}$. The land was opened in late November, 2014 with a tractor drawn plough. Later on, the land was ploughed and cross ploughed three times by a country plough followed by laddering to obtain the desirable tilth. The land was uniformly fertilized with urea, triple super phosphate (TSP), muriate of potash (MoP) and gypsum at the rate of 200, 160, 50 and $120 \mathrm{~kg} \mathrm{ha}^{-1}$ respectively. The entire amount of TSP, MoP and gypsum and two third of urea were applied at the time of final land preparation. The rest one thirds of urea were top dressed at crown root initiation (CRI) stage i.e. 25 days after sowing
(DAS). The crop received two irrigations, one at CRI stage on 25 December 2014 and the other at early booting stage on 1 February, 2015.

The weeds were found in each plot were identified and counted at 45 days after sowing. Weeds from each plot were collected by setting $1 \mathrm{~m}^{2}$ quadrate. Dry weight of weeds were recorded after drying in an oven at $80^{\circ} \mathrm{C}$ for $72 \mathrm{hr}$. Five plants were selected randomly from each plot prior to harvest excluding boarder plants to collect the data on crop and yield contributing characters. The harvested crop of each plot was bundled separately and then carried to the threshing floor. Threshing, cleaning and drying the grain and straw of individual plot were done carefully. Grains were dried carefully up to $14 \%$ moisture content. Straws also sun dried properly. Grain and straw weights were recorded plot wise and converted to $\mathrm{tha}^{-1}$. The collected data were compiled and analyzed statistically by using the statistical package MSTAT and the mean values were adjudged as per Duncan's New Multiple Range Test (Gomez and Gomez, 1984).

\section{Results and Discussion}

\section{Weed Infestation}

Effect of cultivar: The effect of cultivar on weed population and weed dry weight was statistically significant (Table 1). The maximum number of weed population was recorded in BARI Gam 24 (21.90) followed by BARI Gam 26 (19.76) which was statistically significant to BARI Gam 25 (19.57).

Table 1. Effect of wheat cultivar on the weed population and weed dry weight

\begin{tabular}{ccc}
\hline Cultivar & $\begin{array}{c}\text { Weed } \\
\text { population } \\
\text { (no.) }\end{array}$ & $\begin{array}{c}\text { Weed dry } \\
\text { weight } \\
\left(\mathrm{g} \mathrm{m}^{-2}\right)\end{array}$ \\
\hline BARI Gam 24 & $21.90 \mathrm{a}$ & $10.76 \mathrm{a}$ \\
BARI Gam 25 & $19.57 \mathrm{~b}$ & $10.70 \mathrm{a}$ \\
BARI Gam 26 & $19.76 \mathrm{~b}$ & $9.24 \mathrm{~b}$ \\
\hline CV (\%) & 1.29 & 2.59
\end{tabular}

\begin{tabular}{ccc}
\hline $\mathrm{CV}(\%)$ & 1.29 & 2.59 \\
\hline $\begin{array}{c}\text { Level of } \\
\text { significance }\end{array}$ & $* *$ & $* *$ \\
\hline
\end{tabular}

$* *=$ Significant at $1 \%$ level of probability 
The highest dry matter accumulation of weeds was in BARI Gam 24 (10.76 $\left.\mathrm{g} \mathrm{m}^{-2}\right)$ which was statistically identical with BARI Gam $25\left(10.70 \mathrm{~g} \mathrm{~m}^{-2}\right)$ while dry matter accumulation of weeds in BARI Gam 26 was the lowest $\left(9.24 \mathrm{~g} \mathrm{~m}^{-2}\right)$. It might be due to genetical characteristics of the variety. The variety BARI Gam 26 produced the highest grain yield. Contrarily, BARI Gam 24 was the shortest variety with the least production of grain and straw yield. Therefore, it rendered least competition effects on weed growth. From the correlation study, it was evident that the grain yield was negatively related to weed dry weight. This relationship between grain yield and weed dry weight supports the fact that the highly competitive variety lead to greater yield of wheat (Figure 1). This result is in agreement with that of Rashid and Khan (2000).

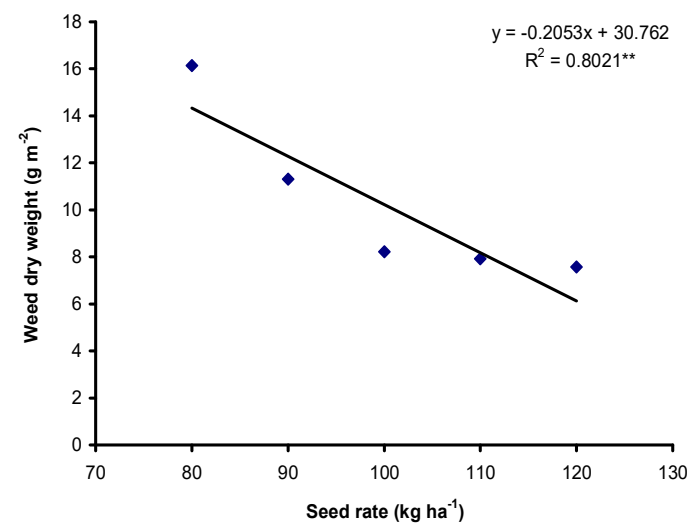

Figure 1. Functional relationship between seed rate of wheat and weed dry weight $\left(\mathrm{g} \mathrm{m}^{-2}\right)$

Effect of seed rate: The seed rate also affect significantly on weed population and weed dry weight. The maximum weed population was observed at seed rate $80 \mathrm{~kg} \mathrm{ha}^{-1}$ (37.11) followed by $90 \mathrm{~kg} \mathrm{ha}^{-1}$ (26.38) and lowest number was recorded in $120 \mathrm{~kg} \mathrm{ha}^{-1}$ (11.82). Similarly, the highest weed dry weight accumulation was noted under the seed rate of $80 \mathrm{~kg} \mathrm{ha}^{-1}\left(16.14 \mathrm{~g} \mathrm{~m}^{-2}\right)$ and the lowest weed growth $\left(7.57 \mathrm{~g} \mathrm{~m}^{-2}\right)$ was found under at seed rate of $120 \mathrm{~kg} \mathrm{ha}^{-1}$. There was vice-versa relationship was found between seed rate of $120 \mathrm{~kg} \mathrm{ha}^{-1}$ and seed rate of $60 \mathrm{~kg} \mathrm{ha}^{-1}$ (Table 2).
Table 2. Effect of seed rate on the weed population and weed dry weight

\begin{tabular}{ccc}
\hline $\begin{array}{c}\text { Seed rate } \\
\left(\mathrm{kg} \mathrm{ha}^{-1}\right)\end{array}$ & $\begin{array}{c}\text { Weed } \\
\text { population } \\
\text { (no.) }\end{array}$ & $\begin{array}{c}\text { Weed dry } \\
\text { weight }\left(\mathrm{g} \mathrm{m}^{-2}\right)\end{array}$ \\
\hline 80 & $37.11 \mathrm{a}$ & $16.14 \mathrm{a}$ \\
90 & $26.38 \mathrm{~b}$ & $11.31 \mathrm{~b}$ \\
100 & $13.74 \mathrm{c}$ & $8.22 \mathrm{c}$ \\
110 & $13.00 \mathrm{c}$ & $7.92 \mathrm{c}$ \\
120 & $11.82 \mathrm{c}$ & $7.57 \mathrm{c}$ \\
\hline $\mathrm{CV}(\%)$ & 1.29 & 2.59 \\
\hline Level of & $* *$ & $* *$ \\
significance & & $*$
\end{tabular}

In a column, figures with same letter(s) or without letter do not differ significantly whereas figures with dissimilar letters differ significantly as per DMRT. $* *=$ Significant at $1 \%$ level of probability

Effect of interaction between cultivar and seed rate: The interaction effect of cultivar and seed rate on weed population and dry weight of weed was significant. The maximum number of weeds were recorded in BARI Gam $24 \times$ seed rate of $80 \mathrm{~kg} \mathrm{ha}^{-1}$ (44.67) followed by BARI Gam $26 \times$ seed rate of 80 $\mathrm{kg} \mathrm{ha}^{-1}$ (38.93) and minimum population of weeds were found in (6.25). The highest accumulation of weed dry matter $\left(18.68 \mathrm{~g} \mathrm{~m}^{-2}\right)$ was noted in BARI Gam 24 and seed rate $80 \mathrm{~kg} \mathrm{ha}^{-1}$ followed by BARI Gam 25 and seed rate $80 \mathrm{~kg} \mathrm{ha}^{-1}$. The lowest weed growth $\left(4.56 \mathrm{~g} \mathrm{~m}^{-2}\right)$ was marked in BARI Gam 24 grown at the rate of $100 \mathrm{~kg} \mathrm{ha}^{-1}$ which was statistically identical to BARI Gam 26 at $120 \mathrm{~kg} \mathrm{ha}^{-1}$ seed rate (Table 3 ).

\section{Effect on yield contributing characters and yield of wheat}

Effect of cultivar: The variety had significant influenced crop characters, yield contributing characters and yield of wheat. The highest plant height $(93.27 \mathrm{~cm})$ was recorded in BARI Gam 25 which was statistically identical with BARI Gam 26 and the lowest height $(87.93 \mathrm{~cm})$ was found in BARI Gam 24. The highest number of total tillers was obtained (5.01) from BARI Gam 24 followed by BARI Gam 25 (4.83) and lowest one was BARI Gam 26 (3.99). The highest number of effective tillers plant $^{-1}$ (3.69) was found in the variety BARI Gam 25 which was statistically identical to BARI Gam 24 
(3.59) and the lowest one in BARI Gam 26. The highest number of grains spike ${ }^{-1}$ (34.51) was obtained in BARI Gam 26 and the lowest grains spike ${ }^{-1}$ (30.38) was found in BARI Gam 25. BARI Gam 25 gave the heaviest grain weight (44.51g), which was statistically identical with the variety BARI Gam 24 (44.01g) and the lowest grain weight was observed in BARI Gam 26 (42.22g) (Table 4).

Table 3. Effect of interaction of wheat cultivar and seed rate on the weed population and weed dry weight

\begin{tabular}{ccc}
\hline $\begin{array}{c}\text { Cultivar } \times \\
\text { Seed rate }\end{array}$ & $\begin{array}{c}\text { Weed } \\
\text { population } \\
\text { (no.) }\end{array}$ & $\begin{array}{c}\text { Weed dry } \\
\text { weight }\left(\mathrm{g} \mathrm{m}^{-2}\right)\end{array}$ \\
\hline $\mathrm{V}_{1} \times \mathrm{S}_{1}$ & $44.67 \mathrm{a}$ & $18.68 \mathrm{a}$ \\
$\mathrm{V}_{1} \times \mathrm{S}_{2}$ & $33.22 \mathrm{c}$ & $13.86 \mathrm{~b}$ \\
$\mathrm{~V}_{1} \times \mathrm{S}_{3}$ & $6.25 \mathrm{i}$ & $4.56 \mathrm{i}$ \\
$\mathrm{V}_{1} \times \mathrm{S}_{4}$ & $12.90 \mathrm{gh}$ & $9.00 \mathrm{def}$ \\
$\mathrm{V}_{1} \times \mathrm{S}_{5}$ & $12.47 \mathrm{gh}$ & $7.68 \mathrm{fg}$ \\
$\mathrm{V}_{2} \times \mathrm{S}_{1}$ & $27.73 \mathrm{~d}$ & $15.47 \mathrm{~b}$ \\
$\mathrm{~V}_{2} \times \mathrm{S}_{2}$ & $25.77 \mathrm{~d}$ & $10.77 \mathrm{c}$ \\
$\mathrm{V}_{2} \times \mathrm{S}_{3}$ & $18.00 \mathrm{ef}$ & $9.81 \mathrm{cde}$ \\
$\mathrm{V}_{2} \times \mathrm{S}_{4}$ & $13.37 \mathrm{fgh}$ & $8.21 \mathrm{ef}$ \\
$\mathrm{V}_{2} \times \mathrm{S}_{5}$ & $13.00 \mathrm{gh}$ & $9.24 \mathrm{c}-\mathrm{f}$ \\
$\mathrm{V}_{3} \times \mathrm{S}_{1}$ & $38.93 \mathrm{~b}$ & $14.28 \mathrm{~b}$ \\
$\mathrm{~V}_{3} \times \mathrm{S}_{2}$ & $20.17 \mathrm{e}$ & $9.30 \mathrm{c}-\mathrm{f}$ \\
$\mathrm{V}_{3} \times \mathrm{S}_{3}$ & $16.97 \mathrm{efg}$ & $10.30 \mathrm{~cd}$ \\
$\mathrm{~V}_{3} \times \mathrm{S}_{4}$ & $12.73 \mathrm{gh}$ & $6.53 \mathrm{gh}$ \\
$\mathrm{V}_{3} \times \mathrm{S}_{5}$ & $10.00 \mathrm{hi}$ & $5.79 \mathrm{hi}$ \\
\hline $\mathrm{CV}(\%)$ & 1.29 & 2.59 \\
\hline Level of & $* *$ & $* *$ \\
significance & & \\
\hline
\end{tabular}

In a column, figures with same letter(s) or without letter do not differ significantly whereas figures with dissimilar letters differ significantly as per DMRT.

$\mathrm{V}_{1}=$ BARI Gam 24, $\mathrm{V}_{2}=$ BARI Gam 25, $\mathrm{V}_{3}=$ BARI Gam $26, \mathrm{~S}_{1}=80 \mathrm{~kg} \mathrm{ha}^{-1}, \mathrm{~S}_{2}=90 \mathrm{~kg} \mathrm{ha}^{-1}, \mathrm{~S}_{3}=100 \mathrm{~kg} \mathrm{ha}^{-1}, \mathrm{~S}_{4}=$ $110 \mathrm{~kg} \mathrm{ha}^{-1}, \mathrm{~S}_{5}=120 \mathrm{~kg} \mathrm{ha}^{-1}$

$* *=$ Significant at $1 \%$ level of probability

The highest grain yield $\left(2.51 \mathrm{t} \mathrm{ha}^{-1}\right)$ was obtained in BARI Gam 26 which was statistically identical to BARI Gam $25\left(2.48 \mathrm{t} \mathrm{ha}^{-1}\right)$ and the lowest grain yield (1.78 t $\mathrm{ha}^{-1}$ ) was obtained from BARI Gam 24. The effects of variety on the number of grains spike ${ }^{-1}$ have been reflected on the grain yield of the variety. BARI Gam 25 produced the highest straw yield (3.43) which was as good as BARI Gam 26 (3.42). The highest harvest index (42.30\%) was obtained from BARI Gam 25 and the lowest one $(38.10 \%)$ was obtained from BARI Gam 24 (Table 4).

Effect of seed rate: The effect of seed rate on plant height, no. of total tillers plant ${ }^{-1}$, no. of effective tillers plant $^{-1}$, no. of grains spike ${ }^{-1}, 1000$-grain weight $(\mathrm{g})$, grain yield $\left(\mathrm{t} \mathrm{ha}^{-1}\right)$, straw yield $\left(\mathrm{t} \mathrm{ha}^{-1}\right)$ and harvest index (\%) was also statistically significant . The tallest plant $(93.37 \mathrm{~cm})$ was obtained at $110 \mathrm{~kg} \mathrm{ha}^{-1}$ which was statistically identical to 100 $\mathrm{kg} \mathrm{ha}^{-1}$ and the lowest height $(88.11 \mathrm{~cm})$ at $90 \mathrm{~kg} \mathrm{ha}^{-1}$. The highest number of tillers plant ${ }^{-1}$ (6.03) was obtained in the seed rate of $100 \mathrm{~kg} \mathrm{ha}^{-1}$ followed by seed rate of $100 \mathrm{~kg} \mathrm{ha}^{-1}$ (5.67) and the lowest number of tillers (2.85) was found in case of seed rate $80 \mathrm{~kg}$ $\mathrm{ha}^{-1}$ (Table 5). Optimum seed rate $\left(100 \mathrm{~kg} \mathrm{ha}^{-1}\right)$ can fulfill the demand of crop plants which positively affect the total tillers plant ${ }^{-1}$. The highest number of effective tiller plant ${ }^{-1}$ (4.91) was noted at seed rate $100 \mathrm{~kg} \mathrm{ha}^{-1}$ and the lowest number of effective tiller (2.03) was at seed rate $80 \mathrm{~kg} \mathrm{ha}^{-1}$. The highest number of grains spike ${ }^{-1}$ (41.06) was in $100 \mathrm{~kg} \mathrm{ha}^{-1}$ seed rate which was statistically identical with 110 $\mathrm{kg} \mathrm{ha}^{-1}$ and the lowest number of grain was at seed rate $80 \mathrm{~kg} \mathrm{ha}^{-1}$. The heaviest grain weight (45.36 g) was noted in $110 \mathrm{~kg} \mathrm{ha}^{-1}$ seed rate. The lowest grain weight $(40.44 \mathrm{~g})$ was obtained at the seed rate $90 \mathrm{~kg}$ $\mathrm{ha}^{-1}$. The highest grain yield $\left(2.99 \mathrm{t} \mathrm{ha}^{-1}\right)$ was obtained by the seed rate of $100 \mathrm{~kg} \mathrm{ha}^{-1}$ followed by $100 \mathrm{~kg} \mathrm{ha}^{-1}$ seed rate and the lowest grain yield (1.39 $\mathrm{t} \mathrm{ha}^{-1}$ ) was produced at of $80 \mathrm{~kg} \mathrm{ha}^{-1}$ seed rate. Maximum plant population was produced in $120 \mathrm{~kg}$ $\mathrm{ha}^{-1}$ of seed rate which lead to higher intra-plant competition and the production of grain yield was affected accordingly. Talukder et al. (2004) reported that the highest grain yield $\left(4.16 \mathrm{tha}^{-1}\right)$ was obtained from $100 \mathrm{~kg} \mathrm{ha}^{-1}$ of seed rate in wheat. The highest straw yield $\left(3.93 \mathrm{t} \mathrm{ha}^{-1}\right)$ was produced by the seed rate of $110 \mathrm{~kg} \mathrm{ha}^{-1}$ and the lowest $\left(2.31 \mathrm{t} \mathrm{ha}^{-1}\right)$ at the seed rate of $80 \mathrm{~kg} \mathrm{ha}^{-1}$. The highest harvest index $(43.48 \%)$ was found at $100 \mathrm{~kg} \mathrm{ha}^{-1}$ seed rate and the lowest one $(37.98 \%)$ was at $80 \mathrm{~kg} \mathrm{ha}^{-1}$ seed rate.

Effect of interaction between variety and seed rate: Different yield contributing characters and yield of wheat were significantly affected by interaction between variety and seed rate (Table 6). The highest 
plant height was noticed in interaction between the variety BARI Gam 25 and the seed rate of $100 \mathrm{~kg}$ ha ${ }^{1}$ followed by BARI Gam 26 and the seed rate of 100 and $110 \mathrm{~kg} \mathrm{ha}^{-1}$, respectively. The lowest plant height was found in BARI Gam 24 at $90 \mathrm{~kg} \mathrm{ha}^{-1}$ seed rate (Table 6). The highest number of total tillers plant ${ }^{-1}$ (6.53) was obtained in BARI Gam 25 at seed rate of
$100 \mathrm{~kg} \mathrm{ha}^{-1}$ which was statistically identical with BARI Gam 24 and seed rate $110 \mathrm{~kg} \mathrm{ha}^{-1}$ and the lowest number of total tillers plant ${ }^{-1}$ (3.26) was obtained in BARI Gam 24 with the seed rates $80 \mathrm{~kg}$ $\mathrm{ha}^{-1}$ which was statistically identical with BARI Gam 25 with at seed rate $90 \mathrm{~kg} \mathrm{ha}{ }^{-1}$ (Table 6).

Table 4. Effect of cultivar on the crop performance of wheat

\begin{tabular}{|c|c|c|c|c|c|c|c|}
\hline Cultivar & $\begin{array}{l}\text { Plant } \\
\text { height } \\
(\mathrm{cm})\end{array}$ & $\begin{array}{l}\text { Total } \\
\text { tillers } \\
\text { plant }^{-1}\end{array}$ & $\begin{array}{c}\text { No. of } \\
\text { effective } \\
\text { tillers hill }^{-1}\end{array}$ & $\begin{array}{l}\text { No. of } \\
\text { grains } \\
\text { spike }^{-1}\end{array}$ & $\begin{array}{l}\text { 1000-grain } \\
\text { weight }(\mathrm{g})\end{array}$ & $\begin{array}{c}\text { Straw } \\
\text { yield } \\
\left(\mathrm{t} \mathrm{ha}^{-1}\right)\end{array}$ & $\begin{array}{c}\text { Harvest } \\
\text { index } \\
(\%)\end{array}$ \\
\hline BARI Gam 24 & $87.93 b$ & $5.01 \mathrm{a}$ & $3.59 \mathrm{ab}$ & $33.56 \mathrm{~b}$ & $44.01 \mathrm{ab}$ & $2.88 \mathrm{~b}$ & $38.10 \mathrm{~b}$ \\
\hline BARI Gam 25 & $93.27 \mathrm{a}$ & $4.83 \mathrm{~b}$ & $3.69 \mathrm{a}$ & $30.38 \mathrm{c}$ & $44.51 \mathrm{a}$ & $3.43 \mathrm{a}$ & $42.30 \mathrm{a}$ \\
\hline BARI Gam 26 & $93.03 \mathrm{ab}$ & $3.99 \mathrm{c}$ & $3.09 \mathrm{~b}$ & $34.51 \mathrm{a}$ & $42.22 b$ & $3.42 \mathrm{a}$ & $41.94 \mathrm{a}$ \\
\hline CV (\%) & 3.17 & 5.69 & 6.65 & 4.13 & 3.09 & 4.48 & 3.78 \\
\hline $\begin{array}{c}\text { Level of } \\
\text { significance }\end{array}$ & $* *$ & $* *$ & $* *$ & $* *$ & $* *$ & $* *$ & $* *$ \\
\hline
\end{tabular}

Table 5. Effect of seed rate on the crop performance of wheat

\begin{tabular}{cccccccc}
\hline $\begin{array}{c}\text { Seed rate } \\
\left(\mathrm{kg} \mathrm{ha}^{-1}\right)\end{array}$ & $\begin{array}{c}\text { Plant } \\
\text { height }(\mathrm{cm})\end{array}$ & $\begin{array}{c}\text { Total } \\
\text { tillers } \\
\text { plant }^{-1}\end{array}$ & $\begin{array}{c}\text { No. of } \\
\text { effective } \\
\text { tillers hill }^{-1}\end{array}$ & $\begin{array}{c}\text { No. of } \\
\text { grains } \\
\text { spike }\end{array}$ & $\begin{array}{c}1000 \text {-grain } \\
\text { weight }(\mathrm{g})\end{array}$ & $\begin{array}{c}\text { Straw } \\
\text { yield } \\
\left(\mathrm{t} \mathrm{ha}^{-1}\right)\end{array}$ & $\begin{array}{c}\text { Harvest } \\
\text { index } \\
(\%)\end{array}$ \\
\hline 80 & $90.48 \mathrm{bc}$ & $2.85 \mathrm{e}$ & $2.03 \mathrm{~d}$ & $21.00 \mathrm{c}$ & $42.68 \mathrm{~b}$ & $2.31 \mathrm{~b}$ & $37.98 \mathrm{~b}$ \\
90 & $88.11 \mathrm{c}$ & $3.19 \mathrm{~d}$ & $2.14 \mathrm{~d}$ & $23.44 \mathrm{c}$ & $40.44 \mathrm{c}$ & $2.37 \mathrm{~b}$ & $\begin{array}{c}42.66 \mathrm{a} \\
100\end{array}$ \\
$93.35 \mathrm{a}$ & $6.03 \mathrm{a}$ & $4.91 \mathrm{a}$ & $41.06 \mathrm{a}$ & $44.60 \mathrm{a}$ & $3.87 \mathrm{a}$ & $43.48 \mathrm{a}$ \\
110 & $93.37 \mathrm{a}$ & $5.67 \mathrm{~b}$ & $4.69 \mathrm{~b}$ & $40.34 \mathrm{ab}$ & $45.36 \mathrm{a}$ & $3.93 \mathrm{a}$ & $41.22 \mathrm{ab}$ \\
120 & $91.74 \mathrm{ab}$ & $5.31 \mathrm{c}$ & $3.52 \mathrm{c}$ & $38.26 \mathrm{~b}$ & $44.82 \mathrm{a}$ & $3.72 \mathrm{a}$ & $38.57 \mathrm{~b}$ \\
\hline CV $(\%)$ & 3.17 & 5.69 & 6.65 & 4.13 & 3.09 & 4.48 & 3.78 \\
\hline $\begin{array}{c}\text { Level of } \\
\text { significance }\end{array}$ & $* *$ & $* *$ & $* *$ & $* *$ & $* *$ & $* *$ & $* *$ \\
\hline
\end{tabular}

In a column, figures with same letter(s) or without letter do not differ significantly whereas figures with dissimilar letters differ significantly as per DMRT. $* *=$ Significant at $1 \%$ level of probability

The highest number of effective tiller (5.35) was noted due to interaction effect of variety BARI Gam 24 and the seed rate $100 \mathrm{~kg} \mathrm{ha}^{-1}$ which was followed by BARI Gam $25(5.14)$ and the seed rate $110 \mathrm{~kg} \mathrm{ha}^{-1}$ (Table 6). The lowest number of effective tillers plant $^{-1}$ (1.83) was recorded from the interaction of seed rate $80 \mathrm{~kg} \mathrm{ha}^{-1}$ with the variety BARI Gam 24 . In case of no. of grains spike ${ }^{-1}$ the highest value (43.77) was obtained in the combination of BARI Gam 24 with $110 \mathrm{~kg}$ seed $\mathrm{ha}^{-1}$. The lowest grain number (19.83) was marked in combination of BARI Gam 25 under seed rate $80 \mathrm{kgha}^{-1}$ (Table 6). The highest grain weight $(47.61 \mathrm{~g})$ was noted in BARI
Gam 25 at seed rate of $110 \mathrm{~kg} \mathrm{ha}^{-1}$ and the lowest weight was in BARI Gam 24 at $90 \mathrm{~kg} \mathrm{ha}^{-1}$ seed rate $(37.96 \mathrm{~g})$. The highest grain yield $\left(3.45 \mathrm{t} \mathrm{ha}^{-1}\right)$ was observed from the variety BARI Gam 26 with the seed rate of $100 \mathrm{~kg} \mathrm{ha}^{-1}$ followed by $\left(3.08 \mathrm{t} \mathrm{ha}^{-1}\right)$ BARI Gam 25 at $100 \mathrm{~kg} \mathrm{ha}^{-1}$ seed rate and the lowest yield $\left(0.96 \mathrm{tha}^{-1}\right)$ was obtained in BARI Gam 24 where the crop was sown with the seed rate of $80 \mathrm{~kg} \mathrm{ha}^{-1}$ (Table 6). There were a good number of variations in different combination of the factors, which indicates the grain production of wheat varieties varied with different seed rates. The highest straw yield (4.27 t $\mathrm{ha}^{-1}$ ) was produced in BARI Gam 25 at $100 \mathrm{~kg} \mathrm{ha}^{-1}$ 
seed rate while the lowest straw yield $\left(1.67 \mathrm{t} \mathrm{ha}^{-1}\right)$ was obtained in BARI Gam 24 with $80 \mathrm{~kg} \mathrm{ha}^{-1}$ seed rate which is statically identical to BARI Gam 24 under the seed rate of $90 \mathrm{~kg} \mathrm{~h}^{-1}$. The highest plant height and higher number of total tillers plant ${ }^{-1}$ were led the highest straw yield in BARI Gam 25 at 100 $\mathrm{kg} \mathrm{ha}^{-1}$ seed rate. Harvest index was the highest $(48.62 \%)$ in BARI Gam 26 under seed rate $90 \mathrm{~kg} \mathrm{ha}^{-1}$ which was statistically identical (48.05\%) with BARI Gam 26 at $100 \mathrm{~kg} \mathrm{ha}^{-1}$ seed rate and the lowest harvest index (31.41\%) was found in BARI Gam 26 with $80 \mathrm{~kg} \mathrm{ha}^{-1}$ seed rate.

Table 6. Effect of interaction between cultivar and seed rate on the crop performance of wheat

\begin{tabular}{|c|c|c|c|c|c|c|c|c|}
\hline $\begin{array}{l}\text { Cultivar } \times \\
\text { Seed rate }\end{array}$ & $\begin{array}{l}\text { Plant } \\
\text { height } \\
(\mathrm{cm})\end{array}$ & $\begin{array}{l}\text { Total } \\
\text { tillers } \\
\text { plant } \\
1 \text { (no.) }\end{array}$ & $\begin{array}{c}\text { Effective } \\
\text { tillers } \\
\text { plant }^{-1} \\
\text { (no.) }\end{array}$ & $\begin{array}{l}\text { Grains } \\
\text { spike }^{-1} \\
\text { (no.) }\end{array}$ & $\begin{array}{c}\text { 1000-grain } \\
\text { weight } \\
(\mathrm{g})\end{array}$ & $\begin{array}{c}\text { Grain } \\
\text { yield } \\
\left(\mathrm{t} \mathrm{ha}^{-1}\right)\end{array}$ & $\begin{array}{c}\text { Straw } \\
\text { yield } \\
\left(\mathrm{t} \mathrm{ha}^{-1}\right)\end{array}$ & $\begin{array}{c}\text { Harvest } \\
\text { index } \\
(\%)\end{array}$ \\
\hline $\mathrm{V}_{1} \times \mathrm{S}_{1}$ & $88.06 \mathrm{~d}$ & $3.26 \mathrm{e}$ & $1.83 \mathrm{~h}$ & $20.16 \mathrm{e}$ & $42.83 \mathrm{bcd}$ & $0.96 \mathrm{i}$ & $1.67 \mathrm{~h}$ & $36.12 \mathrm{de}$ \\
\hline $\mathrm{V}_{1} \times \mathrm{S}_{2}$ & $80.73 \mathrm{e}$ & $3.13 \mathrm{ef}$ & $1.92 \mathrm{gh}$ & $20.30 \mathrm{e}$ & $37.96 \mathrm{e}$ & $1.17 \mathrm{i}$ & $1.85 \mathrm{~h}$ & $39.01 \mathrm{~cd}$ \\
\hline $\mathrm{V}_{1} \times \mathrm{S}_{3}$ & $89.81 \mathrm{bcd}$ & $6.27 \mathrm{ab}$ & $5.35 \mathrm{a}$ & $40.27 \mathrm{a}$ & $45.58 \mathrm{ab}$ & $2.43 \mathrm{~cd}$ & $3.60 \mathrm{cde}$ & $40.49 \mathrm{bcd}$ \\
\hline $\mathrm{V}_{1} \times \mathrm{S}_{4}$ & $92.66 a-d$ & $6.44 a$ & $5.13 \mathrm{a}$ & $43.77 \mathrm{a}$ & $46.86 a$ & $2.27 \mathrm{de}$ & $3.87 \mathrm{abc}$ & $36.98 \mathrm{de}$ \\
\hline $\mathrm{V}_{1} \times \mathrm{S}_{5}$ & $88.40 \mathrm{~cd}$ & $5.96 \mathrm{~b}$ & $3.74 d$ & $43.30 \mathrm{a}$ & $46.83 a$ & $2.07 \mathrm{ef}$ & $3.40 \mathrm{de}$ & $37.93 d$ \\
\hline $\mathrm{V}_{2} \times \mathrm{S}_{1}$ & $92.67 a-d$ & $2.77 \mathrm{fg}$ & $2.14 \mathrm{fg}$ & $19.83 \mathrm{e}$ & $43.28 \mathrm{bcd}$ & $1.74 \mathrm{gh}$ & $2.01 \mathrm{gh}$ & $46.42 \mathrm{ab}$ \\
\hline $\mathrm{V}_{2} \times \mathrm{S}_{2}$ & $90.86 a-d$ & $3.33 \mathrm{e}$ & $2.17 \mathrm{fg}$ & $25.52 d$ & $41.10 \mathrm{~d}$ & $1.92 \mathrm{fg}$ & $2.86 f$ & $40.36 \mathrm{bcd}$ \\
\hline $\mathrm{V}_{2} \times \mathrm{S}_{3}$ & $95.52 \mathrm{a}$ & $6.53 a$ & $4.79 b$ & $39.93 a$ & $45.15 \mathrm{abc}$ & $3.08 \mathrm{~b}$ & $4.27 \mathrm{a}$ & $41.90 \mathrm{bcd}$ \\
\hline $\mathrm{V}_{2} \times \mathrm{S}_{4}$ & $93.69 \mathrm{ab}$ & $5.97 b$ & $5.14 \mathrm{a}$ & $35.53 b$ & $47.61 \mathrm{a}$ & $2.99 \mathrm{~b}$ & $4.13 \mathrm{ab}$ & $42.00 \mathrm{bcd}$ \\
\hline $\mathrm{V}_{2} \times \mathrm{S}_{5}$ & $93.60 \mathrm{ab}$ & $5.53 \mathrm{c}$ & $4.19 c$ & $31.11 \mathrm{c}$ & $45.44 \mathrm{ab}$ & $2.67 \mathrm{c}$ & $3.87 \mathrm{abc}$ & $40.84 \mathrm{bcd}$ \\
\hline $\mathrm{V}_{3} \times \mathrm{S}_{1}$ & $90.71 \mathrm{a}-\mathrm{d}$ & $2.53 \mathrm{~g}$ & $2.11 \mathrm{fgh}$ & 23.00de & $41.95 d$ & $1.48 \mathrm{~h}$ & $3.24 \mathrm{ef}$ & $31.41 \mathrm{e}$ \\
\hline $\mathrm{V}_{3} \times \mathrm{S}_{2}$ & $92.75 a-d$ & $3.11 \mathrm{ef}$ & $2.33 \mathrm{f}$ & $24.50 \mathrm{de}$ & $42.25 \mathrm{~cd}$ & $2.28 \mathrm{de}$ & $2.41 \mathrm{~g}$ & $48.62 \mathrm{a}$ \\
\hline $\mathrm{V}_{3} \times \mathrm{S}_{3}$ & $94.71 \mathrm{ab}$ & $5.27 \mathrm{c}$ & $4.59 b$ & $42.98 \mathrm{a}$ & $43.07 \mathrm{bcd}$ & $3.45 \mathrm{a}$ & $3.73 \mathrm{bcd}$ & $48.05 a$ \\
\hline $\mathrm{V}_{3} \times \mathrm{S}_{4}$ & $93.76 \mathrm{ab}$ & $4.60 \mathrm{~d}$ & $3.80 \mathrm{~d}$ & $41.71 \mathrm{a}$ & $41.63 d$ & $3.06 \mathrm{~b}$ & $3.79 \mathrm{bcd}$ & $44.69 \mathrm{abc}$ \\
\hline $\mathrm{V}_{3} \times \mathrm{S}_{5}$ & $93.22 \mathrm{abc}$ & $4.44 d$ & $2.63 \mathrm{e}$ & $40.36 \mathrm{a}$ & $42.19 \mathrm{~cd}$ & $2.29 \mathrm{de}$ & $3.90 \mathrm{abc}$ & $36.95 \mathrm{de}$ \\
\hline CV (\%) & 3.17 & 5.69 & 6.65 & 4.13 & 3.09 & 3.94 & 4.48 & 3.78 \\
\hline $\begin{array}{c}\text { Level of } \\
\text { significance }\end{array}$ & $* *$ & $* *$ & $* *$ & $* *$ & $* *$ & $* *$ & $* *$ & $* *$ \\
\hline
\end{tabular}

In a column, figures with same letter(s) or without letter do not differ significantly whereas figures with dissimilar letters differ significantly as per DMRT. $\mathrm{V}_{1}=$ BARI Gam 24, $\mathrm{V}_{2}=$ BARI Gam 25, $\mathrm{V}_{3}=$ BARI Gam 26, $\mathrm{S}_{1}=80 \mathrm{~kg} \mathrm{ha}^{-1}, \mathrm{~S}_{2}=90 \mathrm{~kg}$ $\mathrm{ha}^{-1}, \mathrm{~S}_{3}=100 \mathrm{~kg} \mathrm{ha}^{-1}, \mathrm{~S}_{4}=110 \mathrm{~kg} \mathrm{ha}^{-1}, \mathrm{~S}_{5}=120 \mathrm{~kg} \mathrm{ha}^{-1}$, ** = Significant at $1 \%$ level of probability

\section{Conclusion}

Results of the present study indicated that variety BARI Gam 26 was better than other two varieties. Seed rate $100 \mathrm{~kg} \mathrm{ha}^{-1}$ was optimum in case of highest grain yield of wheat. So it can be concluded that variety BARI Gam 26 at $100 \mathrm{~kg} \mathrm{ha}^{-1}$ seed rate could be the promising combination to obtain maximum grain yield of wheat.

\section{References}

BBS (2013). Statistical Pocket Book of Bangladesh. Bangladesh Bur. Stat., Stat. Div., Minist.
Planning, Govt. People's Rep. Bangladesh. p. 211.

FAO (2013). Production Yearbook. Food and Agriculture Organization, Rome. 54: 79-90.

Gail AW, Nordquist PT, Baenziger PS, Klein NR, Hammons RH (2004). Winter wheat cultivar characteristics affect Annual weed suppression. Weed Journal of Australia, Vol. 18. pp. 988998.

Gomez KA, Gomez AA (1984). Statistical Procedures for Agricultural Research. Int. Rice Res. Inst., John Wiley and Sons. New 
York, Chichester, Brisbane, Toronto, Singapore, p. 680.

Hasan MA (1995). A study on the effect of fertilization on grain yield and grain protein content of two varieties of wheat. MS thesis, Dept. of Agron., Bangladesh Agricultural University, Mymensingh.

Oerke EC, Dehne HW, Schonbeck F, Weber A (1994). Crop production and crop protection: Estimated losses in major food and cash crops. Elsevier, Amsterdam.

Rashid MM, Khan AH (2000). Effect of weed control and yield performance of three weed varieties. MS Thesis, Department of Agronomy, Bangladesh Agricultural University, Mymensingh.

Reddy TY, Reddi GHS (2011). Principles of Agronomy. Kalyani Publishers, Noida, India. p. 527.
Singh A, Singh O (1987). Response of late sown wheat to seed rate and nitrogen. Indian $\mathrm{J}$. Agron. 32 (2): 290-291.

Talukder ASM, Sufian MA, Dxbury JM, Lauren JG, Meinser CA (2004). Effect of tillage options and seed rate on grain yield of wheat. J. Sbtrop. Agric. Res. Dev. 2 (3): 57-62.

UNDP, FAO (1988). Land resources appraisal of Bangladesh for Agricultural Development, Report-2. Agro-ecological Regions of Bangladesh. BARC. UNDP. New Airport Road, Farmgate, Dhaka-1215. pp. 212-221.

Vukadinovic VM, Calo S, Zuher F (1986). Multiple of factor affecting wheat crop production archive fur Aciur and pfanzenbau and Bodenkunde, Bernbury, German Dem. Repub. No. 5-6: 321-332. 